\title{
Concanavalin A agglutinability of developing mouse trophoblast
}

\author{
J. S. Sobel and L. Nebel \\ Department of Embryology and Teratology, Tel-Aviv University Medical School, \\ Chaim Sheba Medical Centre, Tel-Hashomer, Israel
}

Concanavalin A (Con A) has been extensively utilized to investigate cell surface differences between normal and malignantly transformed cells (Sharon \& Lis, 1972; Nicolson, 1974) and between early and late-stage embryonic cells (Kleinschuster \& Moscona, 1972; Krach, Green, Nicolson \& Oppenheimer, 1974). The preferential agglutinability with Con A of malignant and early embryonic cells has led to the proposal that the presence of Con A agglutinin receptor sites may in some way be correlated with the capacity of these cells to migrate and to infiltrate (Moscona, 1971). In the present study we investigated whether such a correlation obtains in differentiating mouse trophoblast. Utilizing the haemagglutination technique of Furmanski, Phillips \& Lubin (1972) blastocysts were examined for Con A agglutinability on the 4th day of development when the trophoblast consists of a relatively uniform population of cells and on the 5th day when the trophoblast undergoes regional differentiation. At this time the mural trophoblast cells lining the blastocoele stop dividing and undergo transformation into a population of migratory giant cells, whilst the polar trophoblast cells overlying the inner cell mass begin to form the ectoplacental cone (Amoroso, 1952; Gardner \& Papaioannou, 1975).

Blastocysts were obtained from ICR mice as follows. Females aged 25-30 days were induced to superovulate with an i.p. injection of 10 i.u. PMSG (Gestyl: Organon) followed $48 \mathrm{hr}$ later by 10 i.u. HCG (Pregnyl: Organon). The animals were mated overnight and checked for vaginal plugs the next morning. Blastocysts were collected at 82 and $106 \mathrm{hr}$ by flushing the uteri with Dulbecco's medium supplemented with $10 \%$ fetal calf serum. The zona pellucidas of the 4-day blastocysts were removed by carefully sucking the blastocysts in and out of a micropipette with a diameter slightly smaller than that of the blastocysts.

The ability of blastocysts to participate in Con A-mediated binding and agglutinating reactions was assayed with a modification of the haemadsorption technique of Furmanski et al. (1972). The medium employed in the subsequent treatments, unless otherwise indicated, was phosphate-buffered saline (PBS) pH 7.4, containing $0.1 \%$ bovine serum albumin (Sigma Chemical Co.). Outdated erythrocytes, type $\mathrm{O}$ positive (two donors) were washed 3 times, incubated with Con A (MilesYeda) for $10 \mathrm{~min}$ at $37^{\circ} \mathrm{C}$, washed again and suspended at a concentration of $2 \%(\mathrm{v} / \mathrm{v})$. Blastocysts were thoroughly rinsed, incubated with Con $A$ for $10 \mathrm{~min}$ at $4^{\circ} \mathrm{C}$ and rinsed at the same temperature. In some cases blastocysts were treated with trypsin (twice crystallized, Sigma), $0.001 \%$ in PBS for $2 \mathrm{~min}$ at $22^{\circ} \mathrm{C}$, or with neuraminidase (Clostridium perfringens: Sigma), $5 \mathrm{U} / \mathrm{ml}$ in PBS, pH 7.0, for $60 \mathrm{~min}$ at $37^{\circ} \mathrm{C}$, before incubation with Con $\mathrm{A}$. For the haemadsorption tests the blastocysts were added to the appropriate erythrocyte suspension and incubated for $10 \mathrm{~min}$ at $37^{\circ} \mathrm{C}$ with continuous gentle rotary shaking. Blastocysts were then removed and washed, and the number of erythrocytes adhering to the peripheral margin of the blastocysts was counted at a magnification of $\times 250$ by 2 independent observers. To facilitate comparison between 4- and 5-day blastocysts, the preparations were photographed and the amount of the periphery covered with erythrocytes was determined from the dimensions of the blastocysts which were then scored on a scale of 0 to $++++:+$, indicating $10-25 \%$ of the periphery thus covered;,$++ 25-50 \% ;+++, 50-75 \% ;++++, 75-100 \%$.

Erythrocytes adhering to Con A-coated blastocysts serve as markers for the presence and distribution of Con A agglutinin sites on the blastocyst surface. They appeared to be randomly attached to the trophoblast of 4-day blastocysts, but were usually found adhering only to the mural and not to the polar trophoblast of 5-day blastocysts (Pl. 1, Fig. 1). Agglutination was observed at Con A 
concentrations of $100 \mu \mathrm{g} / \mathrm{ml}$ and above (Table 1a) and the reaction was specific, as indicated by the inhibition of haemadsorption in the presence of $50 \mathrm{~mm}-\alpha$-methyl-mannopyranoside. The limiting factor in the haemadsorption reaction is probably endocytosis of Con A (Nicolson, 1974) since blastocysts incubated with Con $\mathrm{A}$ at $37^{\circ} \mathrm{C}$ instead of at $4^{\circ} \mathrm{C}$, or blastocysts coated with Con $\mathrm{A}$ at $4^{\circ} \mathrm{C}$ and prewarmed for a few minutes at $37^{\circ} \mathrm{C}$, did not show subsequent haemadsorption.

Table 1. Concanavalin A-mediated haemadsorption (see text for scoring) with Day-4 and Day- 5 mouse biastocysts

\begin{tabular}{|c|c|c|c|c|c|c|c|c|}
\hline \multirow[b]{2}{*}{ Test } & \multicolumn{8}{|c|}{ Concentration of Con $A(\mu \mathrm{g} / \mathrm{ml})$} \\
\hline & 0 & 10 & 20 & 40 & 100 & 250 & 500 & 1000 \\
\hline $\begin{array}{l}\text { (a) Day-4 (146) and Day-5 (161) } \\
\text { blastocysts treated with Con A } \\
\text { and then with uncoated erythrocyte }\end{array}$ & ${ }^{0}$ & N.T. & 0 & 0 & $+1+1$ & ++ & $+t$ & ++ \\
\hline $\begin{array}{l}\text { (b) Day-4 (129) and Day-5 (115) } \\
\text { blastocysts treated with Con A- } \\
\text { coated erythrocytes }\end{array}$ & 0 & + & ++ & ++++ & ++++ & ++++ & N.T. & N.T. \\
\hline
\end{tabular}

N.T., not tested.

The Con A agglutinability exhibited by the 4-day trophoblast is characteristic of early embryonic cells (Nicolson, 1974). The absence of regional differentiation with respect to Con A agglutinability is consistent with the presence of an homogeneous population of trophoblast cells at this time (3.5 days post coitum, Gardner \& Papaioannou, 1975; blastocyst substage 2, Nadijcka \& Hillman, 1974). The next day, when there is overt differentiation of trophoblast into two distinct populations there is also differentiation with respect to Con A agglutinability, with polar trophoblast losing the capacity to agglutinate while the newly formed giant cells show the same degree of agglutinability as their progenitor cells. The agglutinability exhibited by these terminal stage migratory giant cells is in accord with the hypothesis that Con A agglutinability is related to surface properties associated with migratory behaviour (Moscona, 1971). Polar trophoblast proliferates to form the ectoplacental cone at this time but it is clear that in this system agglutinability is not primarily related to mitotic activity (cf. agglutinability of 4-day trophoblast and terminal 5-day trophoblast). These observations suggest that the subsequent differentiation of secondary giant cells on the periphery of the ectoplacental cone will include changes leading to renewed Con A agglutinability.

Loss of Con A agglutinability may be due to many factors including (1) reduction in the number of receptor sites; (2) loss of receptor mobility; and (3) masking of receptor sites.

That reduction of receptor sites is not the reason for loss in agglutinability by polar trophoblast is indicated by the lack of regional differences in the distribution of Con $\mathrm{A}$ receptor sites on the surface of 5-day blastocysts as determined by the Con A peroxidase reaction (Enders \& Schlafke, 1974). There is also no reduction in the binding of fluorescein-tagged Con $A$ to polar trophoblast (unpublished).

Trypsinization did not induce Con A-mediated haemagglutination in polar trophoblast under the conditions described above. This lack of effect contrasts with the action of trypsin on untransformed cells (Nicolson, 1972) and older embryonic cells (Martinozzi \& Moscona, 1975; McDonough \& Lilien, 1975). Trypsin is believed to render these cells agglutinable by reversing restraints on receptor mobility.

The possibility that Con A receptors on polar trophoblast are masked in some way is suggested by experiments which tested the haemadsorption of Con A-coated erythrocytes to untreated blastocysts. In contrast to the above described assay for agglutinability, adherence of Con A-coated erythrocytes to untreated cells is assumed to be due to simple binding with Con A since such indicator erythrocytes have been shown to adhere to agglutinating and nonagglutinating cells (Furmanski et al., 1972). When tested with blastocysts, adherence of Con A-coated erythrocytes was concentration-dependent up to $40 \mu \mathrm{g} / \mathrm{ml}$ (Table $1 \mathrm{~b}$ ). At this and higher concentrations the 4-day blastocyst and mural trophoblast of 5 -day blastocysts became completely covered with erythrocytes and the 

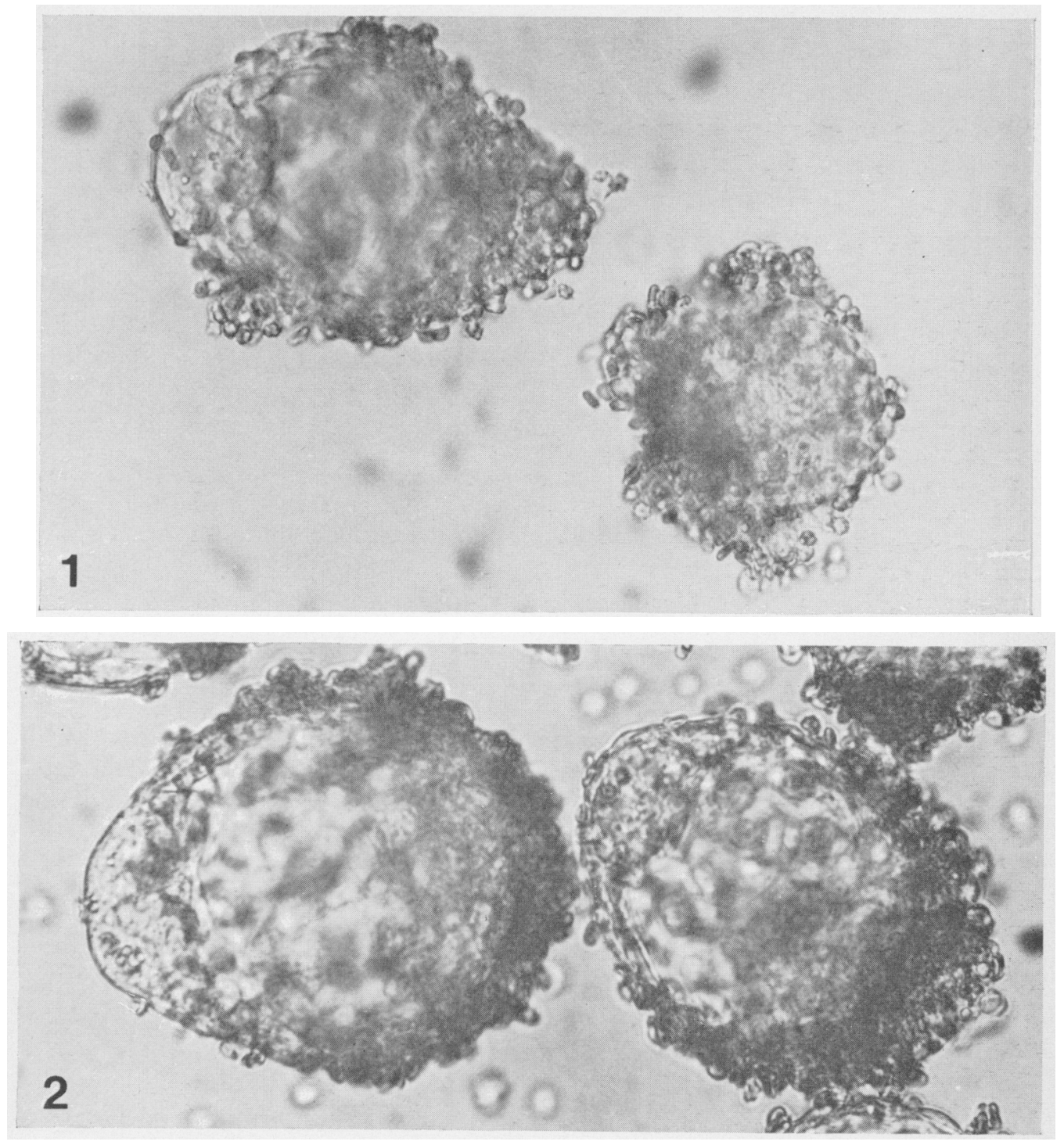

Fig. 1. Adherence of erythrocytes to 5 -day (left) and 4-day (right) blastocysts treated with $500 \mu \mathrm{g} \mathrm{Con} \mathrm{A/ml.}$ Note the absence of erythrocytes on the polar trophoblast of the 5-day blastocyst. $\times 500$.

Fig. 2. Adherence of erythrocytes treated with $40 \mu \mathrm{g}$ Con A/ml to 5-day blastocysts. Blastocysts are densely covered with erythrocytes on the mural trophoblast while the polar trophoblast is almost bare. $\times 500$. 
difference in binding between polar and mural trophoblast was very marked (Pl. 1, Fig. 2). Of 60 such blastocysts (erythrocytes treated with 40-250 $\mathrm{gg}$ Con $\mathrm{A} / \mathrm{ml}$ ), 29 showed no erythrocytes adhering to polar trophoblast, 13 showed a lower density of adherence, and in the remainder there was no difference between polar and mural trophoblast. Loss of binding capacity could not be correlated with any specific advance in development on Day 5. The reaction was abolished in the presence of $50 \mathrm{mM}-\alpha$-methyl-mannopyranoside.

Since polar trophoblast readily binds molecular Con A (Enders \& Schlafke, 1974), the failure to bind indicator erythrocytes may be ascribed to alteration in cell surface properties, e.g. increased surface charge and membrane rigidity, which effectively prevent close contact between trophoblast cells and erythrocytes. Cytoplasmic projections, which are the only surface structures on the polar trophoblast at this time (blastocyst substages 3-4, Nadijcka \& Hillman, 1974), could conceivably cause steric interference, but such projections are more numerous on the nonpolar trophoblast. As a preliminary investigation of the nature of the masking mechanism, the effect of neuraminidase was tested on the haemadsorption reaction. Neuraminidase treatment can cause increased cell surface deformability and reduction in surface charge (Weiss, 1965) and is also reported to uncover surface receptors on trophoblast (Currie, van Doorninck \& Bagshawe, 1968) and malignant (Currie \& Bagshawe, 1968; Schlesinger \& Amos, 1971) cells. Treatment of 5-day blastocysts with neuraminidase had no discernible effect on the polar trophoblast but almost completely inhibited the binding of Con A-coated erythrocytes to the mural trophoblast. The inhibition was reversed in the presence of $1 \%$ mucin. These results indicate an involvement, not necessarily direct (Evans \& Jones, 1974), of sialic acid residues in the Con A-binding reaction and are therefore ambiguous as concerns any masking function on the polar trophoblast.

We thank Mrs Tova Regai for excellent technical assistance.

\section{References}

Amoroso, E.C. (1952) Placentation. In Marshall's Physiology of Reproduction, 3rd edn, Vol. II, pp. 127-311. Ed. A. S. Parkes. Longmans, Green and Co., London.

Currie, G.A. \& Bagshawe, K.D. (1968) The role of sialic acid in antigenic expression: further studies of the Landschutz ascitis tumour. Br. J. Cancer 22, $843-853$.

Currie, G.A., van Doorninck, W. \& Bagshawe, K.D. (1968) Effect of neuraminidase on the immunogenicity of early mouse trophoblast. Nature, Lond. 219, 191-192.

Enders, A.C. \& Schlafke, S. (1974) Surface coats of the mouse blastocyst and uterus during the preimplantation period. Anat. Rec. 180, 31-46.

Evans, P.M. \& JoNes, B.M. (1974) Studies on cellular adhesion-aggregation. Expl Cell Res. 88, 56-62.

Furmanski, P., Phillips, P.G., \& Lubin, M. (1972) Cell surface interactions with Concanavalin A: determination by microhemadsorption. Proc. Soc. exp. Biol. Med. 140, 216-219.

Gardner, R.I. \& Papaioannou, V.E. (1975) Differentiation in the trophectoderm and inner cell mass. In The Early Development of Mammals, pp. 107-132. Eds M. Balls \& A. E. Wild. Cambridge University Press, Cambridge.

Kleinschuster, S.J. \& MosconA, A.A. (1972) Interactions of embryonic and fetal neural retina cells with carbohydrate-binding phytoagglutinins: cell surface changes with differentiation. Expl Cell Res. 70, 397-410.

Krach, S.W., Green, A., Nicolson, G.L. \& OppenHEIMER, S.B. (1974) Cell surface changes occurring during sea urchin embryonic development monitored by quantitative agglutination with plant lectins. Expl Cell Res. 84, 191-198.

Martinozzi, M. \& Moscona, A.A. (1975) Binding of ${ }^{125} \mathrm{I}$-Concanavalin $A$ and agglutination of embryonic neural retina cells. Expl Cell Res. 94, 253-266.

McDonough, J. \& Lilien, J. (1975) Spontaneous and lectin-induced redistribution of cell surface receptors on embryonic chick neural retina cells. J. Cell Sci. 19, 357-368.

Moscona, A.A. (1971) Embryonic and neoplastic cell surfaces: availability of receptors for Concanavalin A and wheat germ agglutinin. Science, N.Y. 171, 905-907.

NAdijcka, M. \& Hillman, N. (1974) Ultrastructural studies of the mouse blastocyst substages. J. Embryol. exp. Morph. 32, 675-695.

Nicolson, G.L. (1972) Topography of membrane concanavalin A sites modified by proteolysis. Nature, New Biol. 239, 193-197.

Nicolson, G.L. (1974) The interactions of lectins with animal cell surfaces. Int. Rev. Cytol. 39, 90-190. 
Schlesinger, M. \& Amos, D.B. (1971) Effect of neuraminidase on serological properties of murine lymphoid cells. Transplant. Proc. 3, 895-897.

SHARON, M. \& LIS, H. (1972) Lectins: cell-agglutinating and sugar specific proteins. Science, N.Y. 177, 949-959.

Weiss, L. (1965) Studies on cell deformability. 1. Effect of surface charge. J. Cell Biol. 26, 735-739.

Received 31 January 1976 